\title{
Pengaruh Efektifitas Pembelajaran Jarak Jauh (PJJ) Mata Pelajaran Pai Terhadap Motivasi Belajar Anak Di Cluster Koba Village Purwakarta
}

\author{
Imam Tabroni $^{1}$, Ismayanti ${ }^{2 *}$, Diaz Budiarti ${ }^{3}$ \\ 1* Pascasarjana Pendidikan Agama Islam, STAI Dr. KH. EZ. Muttaqien, Purwakarta, Indonesia \\ ${ }^{2 *}$ Pendidikan Agama Islam, STAI Dr. KH. EZ. Muttaqien, Purwakarta, Indonesia \\ 3*Pendidikan Agama Islam, STAI Dr. KH. EZ. Muttaqien, Purwakarta, Indonesia \\ Email: ${ }^{1}$ imamtabroni70@gmail.com, ${ }^{2 *}$ budiartidiaz@gmail.com
}

\begin{tabular}{r} 
Informasi Artikel \\
\hline Diterima $: 10-12-2021$ \\
Revisi $: 16-12-2021$ \\
Diterbitkan $: 20-01-2022$ \\
\\
Keywords: \\
\hline Distance Learning Effectiveness \\
Student Learning Motivation
\end{tabular}

Abstrak

Pembelajaran Jarak Jauh khususnya mata pelajaran PAI yang dilaksanakan secara daring atau online. Secara tidak langsung perubahan metode pembelajaran ini berakibat pada keefektifitasan pembelajaran dan hasil belajar. Maka dari itu peneliti mengamati betapa pentingnya peran motivasi bagi siswa dalam melaksanakan Pembelajaran tersebut, dengan harapan keefektifan belajar bisa terus dilakukan dengan maksimal jika motivasi belajar nya juga dinilai baik. Hasil analisis validasi instrument dengan rumus korelasi product moment dengan taraf signifikansi 0.05 menunjukan bahwa variable $\mathrm{x}$ dengan 30 
pernyataan 15 item valid dan 15 item tidak valid, sedngkan variable y dengan 30 pernyataan dengan 18 item valid dan 12 item tidak valid. Nilai koefisien reliabilitas dengan rtabel 0.022 diperoleh 0.327 variable $\mathrm{x}$ dan 0.362 variabel $\mathrm{y}$. Nilai skor angket dari jawaban responden 78 anak pada variable $\mathrm{x}$ (Efektifitas pembelajaran jarak jauh) yaitu 87.6\% dan variable y (Motivasi Belajar Siswa) yaitu 85.7\%. Hasil pengujian hipotesis diperoleh rhitung sebesar dengan nilai koefisien korelasi adalah -0.082 Nilai tersebut berada pada interval $0.00-0.199$ yaitu antara variable x (efektifitas pembelajaran jarak jauh) dan variable y (motivasi belajar siswa) dengan korelasi sangat rendah. Persentase hubungan yaitu sebesar sebesar 0.007 yang artinya variable x (efektifitas pembelajaran jarak jauh) terhadap variable y (motivasi belajar siswa) dipengaruhi oleh variable x sebesar $72.25 \%$ dan sisanya $27.75 \%$ dipengaruhi factor lain diluar variable $\mathrm{x}$ (efektivitas pembelajaran jarak jauh). Nilai Fhitung sebesar $=0.557$ sedangkan Ftabel dengan df $1=\mathrm{k}-1(2-1=1)$ dan df $2=\mathrm{n}-2=78-2=76$ dengan taraf kesalahan $5 \%$ maka nilai Ftabel adalah 3.978 apabila fhitung > ftabel maka Ha diterima dan Ho ditolak. Sedangkan apabila Fhitung < Ftabel maka Ha ditolak dan Ho diterima. Berdasarkan perbandingan nilai diatas, Fhitung $>$ Ftabel maka dapat disimpulkan bahwa Ho diterima dan Ha ditolak, artinya tidak terdapat pengaruh yang signifikan antara variable x (efektifitas pembelajaran jarak jauh) terhadap variable y (motivasi belajar siswa).

Kata Kunci: Efektifitas Pembelajaran Jarak Jauh, Motivasi Belajar Siswa

\section{PENDAHULUAN}

Indonesia adalah salah satu negara yang mengalami dan turut merasakan dampak penyebaran COVID-19, berbagai upaya dan cara terus dilakukan agar segera dapat mengamasa pandemi ini sehingga pemerintah Indonesia menerapkan peringatan kepada masyarakat agar melakukan social distancing dan physical distancing yaitu peringatan untuk jaga jarak dengan menjauhi aktivitas dalam segala bentuk kerumunan, perkumpulan, dan menghindari adanya pertemuan atau kegiatan yang melibatkan banyak masa. Pandemi COVID-19 pun memiliki pengaruh besar terhadap dunia pendidikan yang semula pelaksanaan pembelajaran dilakukan di dalam kelas dengan cara tatap muka antara guru dan siswa, tetapi pada era pandemi ini pelaksanaan pembelajaran dilaksanakan di rumah masing-masing (home-based learning sebagai implikasi dari home-based activity). Dalam konteks ini dan untuk mengatasi permasalahan tersebut, Kemendikbud-RI (Kementerian Pendidikan dan Kebudayaan-Republik Indonesia) mengeluarkan kebijakan dengan merumahkan dan mengganti proses KBM (Kegiatan Belajar Mengajar) dengan menggunakan system online yang dikenal dengan istilah Pembelajaran Jarak Jauh (PJJ, distance learning).

Pembelajaran jarak jauh bukanlah sesuatu yang baru di dunia Pendidikan. Proses pendidikannya biasa dilakukan dengan mengirimkan berbagai materi pembelajaran dan informasi dalam bentuk media cetak dan langsung. Perkembangan teknologi dan komunikasi khususnya perkembangan teknologi computer dengan internetnya, yang sangat pesat dewasa ini berpengaruh terhadap perkembangannya konsep pembelajaran jarak jauh. Internet menjadi media paling tepat dalam pembelajaran jarak jauh karena mampu menembus batas waktu dan tempat atau dapat diakses kapan saja, dimana saja, multivier dan memberikan kemudahan. Dengan teknologi ini informasi dan materi pembelajaran menjadi cepat sampainya.[1]

Kemendikbud-RI menyadari bahwa pandemi COVID-19 ini berpeluang mengancam kualitas pendidikan yang memiliki dampak jangka panjang yang dapat mempengaruhi masa depan pendidikan bangsa Indonesia. Pandemi COVID-19 tengah mengalami metamorfosis yang mengubah wajah dunia pendidikan baik dari sisi metode pembelajaran, penganggaran, hingga sasarannya yang membutuhkan adaptasi agar kegiatan belajar mengajar tetap berjalan efektif. Diantara media yang digunakan dalam sistem Pembelajaran Jarak Jauh (PJJ) yaitu (1) E-learning (2) Aplikasi zoom (3) Google classroom (4) Youtube (5) Media sosial whatsapp. Berbagai media tersebut dapat digunakan sebagai media dalam melangsungkan pembelajaran seperti di dalam kelas.

Penggunaan media internet dalam pembelajaran, tentunya diperlukan bimbingan serta pengawasan yang ketat dari orang tua. Komariah, dkk. (2021, 35) mengemukakan beberapa cara efektif yang dapat diterapkan oleh orang tua dalam mengontrol penggunaan internet, khususnya pada anak, di antaranya: (1) membuat jadwal penggunaan internet, (2) menggunakan metode stopper eksternal dengan melakukan sesuatu yang membuat anak yang adiksi dengan internet untuk log off, (3) membuat batasan waktu penggunaan internet, (4) menjauhkan anak dari aplikasi atau konten yang dapat menyebabkan candu, (5) menggunakan kartu pengingat untuk mengingatkan anak akan bahaya dari kecanduan internet serta manfaat jika terlepas dari rasa candu tersebut. 
Miarso (2004) mengatakan bahwa efektivitas pembelajaran adalah salah satu syarat mutu pendidikan dan sering kali diukur dengan tercapainya tujuan, atau dapat juga diartikan sebagai ketepatan dalam mengatur suatu keadaan, "doing the right things". Menurut Supardi (2013) pembelajaran efektif adalah kombinasi yang tersusun meliputi manusiawi, material, fasilitas, perlengkapan dan prosedur diarahkan untuk mengubah sikap siswa ke arah yang positif dan lebih baik sesuai dengan kemampuan dan perbedaan yang dimiliki siswa untuk mencapai tujuan pembelajaran yang telah ditetapkan. Hamalik (2001) menyatakan bahwa pembelajaran yang efektif adalah proses belajar mengajar yang menyediakan kesempatan belajar sendiri atau melakukan aktivitas seluas-luasnya kepada siswa untuk belajar. Pengadaan kesempatan belajar sendiri dan beraktivitas sebebas bebasnya diharapkan dapat membantu siswa dalam mengetahui konsep yang sedang di pelajari. [3]

Christensen dan Rigby mengatakan Pendidikan jarak jauh merupakan metode pembelajaran yang merupakan korespondensi sebagai sarana untuk berkomunikasi atau berhubungan antara pengajar dan siswa. Salah satu bentuk Pendidikan jarak jauh adalah sekolah korespondensi. Korespondensi merupakan metode pembelajaran menggunakan korespondensi sebagai standar untuk berkomunikasi antara pengajar dengan siswa. Menurut mereka ciri pembelajaran jarak jauh adalah antara pengajar dan siswa melangsungkan pembelajaran secara terpisah, pengajar dan siswa disatukan melalui korespondensi, dan perlu adanya komunikasi atau hubungan antara pengajar dengan siswa. Sehingga arti dari efektifitas dan pembelajarn jarak jauh tidak akan menjadi satu kesatuan tanpa adanya salah satu, Sistem pembelajaran jarak jauh mempunyai ciri yang berbeda dengan praktik pembelajaran konvensional secara tatap muka.[4]

Motivasi belajar adalah dorongan yang timbul dari dalam diri siswa (intrinsik) dan dari luar diri siswa (ekstrinsik) untuk melakukan sesuatu. Motivasi instrinsik meliputi hasrat dan keinginan untuk berhasil, dorongan kebutuhan untuk belajar, dan harapan akan impian siswa. Sedangkan motivasi ekstrinsik yang meliputi adanya reward, lingkungan belajar yang kondusif, kegiatan belajar yang menarik, dan adanya upaya guru dalam mengajar siswa dengan sepenuh hati dan tanggung jawab. Rizal (2016) menjelaskan motivasi yang berasal dari dalam diri pribadi seseorang disebut "motivasi intrinsik", yaitu motif-motif yang menjadi aktif atau berfungsinya tidak perlu ditarik dari luar. Hal ini dikarenakan di dalam diri setiap individu sudah ada dorongan untuk melakukan sesuatu. Sedangkan motivasi yang berasal dari luar diri seseorang disebut "motivasi ekstrinsik", yaitu motif-motif yang aktif dan berfungsi karena adanya perangsang dari luar.[5]

Sulaiman (2016) menjelaskan ilmu pengetahuan dan teknologi berkembang dengan pesat, akibatnya terlihat dengan semakin terbuka dan tersebarnya informasi dan pengetahuan dari dan ke seluruh dunia menembus batas jarak, tempat, ruang, dan waktu. Selain itu, pengaruhnya pun meluas ke berbagai ranah kehidupan termasuk bidang pendidikan.Tujuan pendidikan akan terwujud dalam bentuk perubahan tingkah laku peserta didik melalui proses belajar mengajar, sehingga proses belajar mengajar menjadi unsur yang paling penting dalam mencapai tujuan pendidikan, dengan demikian strategi yang diterapkan oleh pengajar akan berpengaruh besar terhadap tingkat perilaku peserta didik.

Seorang guru hanya sebagai fasilitator, motivator dan inspirator dari proses kegiatan belajar mengajar di kelas, sehingga semua kualitas dari dalam diri anak-anak didiknya, akan terbuka serta keinginan atau tekad dari dalam diri anak itu sendiri yang akan memudahkannya untuk meraih hasil dan tujuan belajar yang maksimal, maka dari itu semua kreativitas,potensi dan bakat minat terletak di dalam diri anak itu sendiri.[7] Implementasi kebijakan yang dikeluarkan oleh pemerintah dengan merumahkan dunia pendidikan selama era pandemi COVID-19 menjadi sorotan penulis untuk dilakukannya penelitian, khususnya PJJ mata pelajaran PAI di Cluster Koba Village Kelurahan Ciseureuh Purwakarta. Jika dilihat dari sudut pandang siswa yang terbiasa mengikuti pembelajaran tatap muka dengan guru dan berdiskusi dengan teman kelas saat pembelajaran berlangsung secara fisik melahirkan kesenangan tersendiri, hal ini mereka tidak dapatkan ketika belajar dari rumah.

Tidak ada teman diskusi ketika siswa mengalami kesulitan, ketiadaan guru secara fisik yang mendampingi siswa selama proses pembelajaran, dan ketidakpahaman orang tua dalam memahami Pembelajaran Jarak Jauh (PJJ) sebagaimana yang dianjurkan pemerintah selama pandemi COVID-19 melahirkan problematika pendidikan tersendiri.[8] Kurangnya sosialisasi pihak sekolah atau pemerintah terhadap cara membimbing anak selama melaksanakan PJJ dirumah juga merupakan faktor pendukung menurunnya kualitas belajar siswa. Terlebih Ketika orang tua siswa yang bekerja maka proses pembelajaran dirumahpun tidak bisa dilakukan dengan maksimal karena siswa tidak ada panutan untuk dia ikuti. 
Dalam masalah ini guru memiliki keterbatasan waktu dalam mengajar melalui media gadget, sebut saja karena faktor sinyal dan kuota internet apalagi bagi siswa yang tinggal diarea pedalaman atau jauh dari pusat kota. Pendidikan Agama Islam (PAI) adalah tiang atau dasar anak untuk memiliki Pendidikan keagamaan. Oleh karena itu Tabroni (2019) [9] menyatakan bahwa keefektifitasannya sangat dibutuhkan untuk melahirkan siswa yang berahlak dan berbudi pekerti, maka jangan sampai karena adanya Pembelajaran Jarak Jauh (PJJ) tidak tercapainya tujuan pembelajaran tersebut.

\section{METODE PENELITIAN}

\subsection{Pendekatan dan Metode Penelitian}

Penelitian ini menggunakan pendekatan kuantitatif dengan jenis penelitian hubungan korelasional. Metode penelitian yang akan digunakan dalam penelitian ini adalah metode korelasional dimana terdiri dari dua variabel yang saling berhubungan yaitu variabel $\mathrm{x}$ efektifitas pembelajaran jarak jauh(Pjj) dan variabel y motivasi belajar siswa.

\subsection{Tempat dan Waktu Penelitian}

Penelitian ini dilaksanakan di Cluster Koba Village Kelurahan Ciseureuh Purwakarta - Jawa Barat. Agar penelitian ini sejalan dengan yang diharapkan peneliti maka ruang lingkupnya adalah seluruh penduduk atau masyarakat Cluster Koba Village khususnya adalah anak anak usia sekolah. Agar terhindarnya dari waktu yang berlebih maka peneliti membatasi waktu penelitian yaitu selama satu bulan, mulai dari Bulan Maret sampai dengan Bulan April 2021.

\subsection{Populasi dan Sampel}

Populasi pada penelitian ini yaitu seluruh anak usia sekolah meliputi SD, SMP dan SMA yang belajar mata pelajaran Pendidikan Agama Islam disekolahnya, di wilayah Cluster Koba Village Kelurahan Ciseureuh Purwakarta. Pengambilan sampel dalam penelitian ini menggunakan teknik Simple Random Sampling. Pengambilan anggota sampel dari populasi dilakukan secara acak tanpa memperhatikan golongan atau tingkatan yang ada dalam populasi itu. Pada penelitian ini sampel yang terpilih adalah anak anak usia sekolah mulai dari SD, SMP dan SMA dengan penentuan kelas eksperimen dan kelas kontrol yang tidak terikat dengan ketentuan-ketentuan/berdasarkan pertimbangan sebelumnya oleh peneliti karena teknik pengambilan yang dipakai adalah random sampel yang sederhana. Adapun penentuan jumlah sampel dari populasi peneliti memakai teori Isaac dan Micahel.[10]

\subsection{Teknik Pengumpulan Data}

Angket ini berupa angket tertutup di mana subjek penelitian hanya diizinkan untuk memilih jawaban yang sudah disediakan oleh peneliti. Skala pengukuran dalam angket penelitian ini menggunakan skala Likert. Angket ini kemudian digunakan sebagai sumber data primer yang diberikan kepada siswa. Berikut empat pilihan jawaban pada pertanyaan variable $\mathrm{X}$ dan $\mathrm{Y}$ dengan skor masing-masing sebagai berikut :

Tabel 1. Skor Angket

\begin{tabular}{|l|l|l|l|}
\hline \multicolumn{2}{|l|}{ Positif } & \multicolumn{2}{l|}{ Negatif } \\
\hline Sangat Tidak Setuju & 1 & Sangat Tidak Setuju & 4 \\
\hline Tidak Setuju & 2 & Tidak Setuju & 2 \\
\hline Setuju & 3 & Setuju & 1 \\
\hline Sangat Setuju & 4 & Sangat Setuju & \\
\hline
\end{tabular}

\subsection{Teknik Analisis Data}

\subsubsection{Deskripsi Data Tiap Variabel}

a. Prosentase

Untuk mengetahui bagaimana sebenarnya efektifitas pembelajaran jarak jauh mata pelajaran PAI terhadap motivasi belajar siswa, maka peneliti melakukan pengukuran dengan menggunakan angket yang terdiri dari pertanyaan pertanyaan yang masing masing pertanyaan disertai empat pilihan jawaban tertutup. Dari keempat alternatif jawaban yang harus dipilih oleh responden kemudian disusun kriteria penilaian sebagai berikut :

a) Nilai komulatif adalah nilai dari setiap item pertanyaan yang merupakan jawaban dari 78 responden

b) Prosentase adalah nilai komulatif item dibagi dengan nilai frekuensinya dilakukan dengan $100 \%$

c) Jumlah responden 78 orang dan nilai skala pengukuran terbesar adalah 4. Sedangkan skala pengukuran terkecil adalah 1. Maka nilai komulatif terbesar adalah 78 x $4=312$ dan jumlah 
komulatif terkecil adalah $78 \times 1=78$. Adapun nilai prosentase terbesar adalah $\frac{78}{312} \times 100 \%=$ $25 \%$. Dari prosentase tertinggi rendah tersebut dapat diperoleh nilai rentang $100 \%-25 \%=$ $75 \%$. Nilai rentang tersebut dibagi 4 skala pengukuran $\frac{75 \%}{4}$. Maka didapat nilai interval prosentase sebesar 19\% dari perhitungan diatas maka dapat ditetapkan klasifikasi kriteria penelitian sebagai berikut :

Tabel 2.Prosentase dan Kriteria Penilaian

\begin{tabular}{|c|c|c|}
\hline No & Prosentase & Kriteria Penilaian \\
\hline 1 & $27.00-45.99$ & Tidak Baik \\
\hline 2 & $46.00-64.99$ & Cukup Baik \\
\hline 3 & $65.00-83.99$ & Baik \\
\hline 4 & $84.00-100.00$ & Sangat Baik \\
\hline
\end{tabular}

b. Ukuran Pemusatan (modus, mean, median)

1) Modus

Modus adalah nilai yang paling sering muncul dalam suatu data statistika. (Avianti, 2007) Modus juga merupakan nilai mayoritas atau nilai dengan frekuensi paling tinggi. Modus dapat digunakan untuk menentukan sampel dari suatu populasi dalam statistika. Dalam penelitian ini peneliti memakai aplikasi SPSS sebagai bahan pengerjaannya.[11] Adapun rumus dari modus adalah sebagai berikut :

$M o=T b+\left(\frac{d 1}{d 1+d 2}\right) p$

Keterangan :

Mo ; Modus

$\mathrm{Tb}$ : Tepi bawah kelas median

$d_{1}$ : Selisih frekuensi kelas modus dengan frekuensi sebelum kelas modus

$d_{2}$ : Selisih frekuensi kelas modus dengan frekuensi setelah kelas modus

$p$ : Panjang interfal

2) Mean

Mean adalah nilai tengah pada suatu kelompok data yang diperoleh dari penjumlahan keseluruhan data pada suatu kelompok dibagi dengan banyaknya data. (Statmat, 2021) Terdapat dua nilai tengah yang biasanya kita ketahui yaitu nilai tengah untuk populasi dan nilai tengah untuk sampel. Nilai tengah biasanya juga disebut mean atau rata-rata. Dalam penelitian ini peneliti memakai aplikasi SPSS sebagai bahan pengerjaannya. Adapun rumus dari mean adalah sebagai berikut :

$$
\begin{aligned}
& \tilde{x}=\frac{\sum x_{i}}{n} \\
& \tilde{x}: \text { Nilai rata rata } \\
& x_{i}: \text { Nilai data ke }-\mathrm{i} \\
& n: \text { Banyaknya data }
\end{aligned}
$$

\section{3) Median}

Median atau nilai tengah adalah salah satu ukuran pemusatan data, yaitu, jika segugus data diurutkan dari yang terkecil sampai yang terbesar atau yang terbesar sampai yang terkecil, nilai pengamatan yang tepat di tengah-tengah bila jumlah datanya ganjil, atau rata-rata kedua pengamatan yang di tengah bila banyaknya pengamatan genap. (E.Walpole, 1993) Dalam penelitian ini peneliti memakai aplikasi SPSS sebagai bahan pengerjaannya. Adapun rumus dari median adalah sebagai berikut :

$\mathrm{Md}=\mathrm{Tb}+\left(\frac{\frac{1}{2} n-f k k}{f i}\right) \ell$

Md : Median

Tb : Banyak data

Fkk : Frekuensi komulatif kurang dari kelas median

fi : Frekuensi kelas median

$\ell$ : Panjang kelas median

c. Ukuran Penyebaran (range, varians, standar deviasi)

1) Range

(Octaviani, 2012) Range adalah perbedaan antara data terbesar dengan data terkecil yang terdapat pada sekelompok data. Range adalah salah satu ukuran statistik yang menunjukan jarak penyebaran data antara nilai terendah (Xmin) dengan nilai tertinggi (Xmax).

Menggunakan nilai tengah 
$\mathrm{R}=x_{i}$ kelas terakhir $-x_{i}$ kelas pertama

Menggunakan nilai batas atas

$\mathrm{R}=$ batas atas kelas terakhir - batas atas kelas pertama

2) Varians dan standar deviasi

Varians dan Standar deviasi adalah sebuah ukuran penyebaran yang menunjukkan standar penyimpangan atau deviasi data terhadap penyimpangan rata-ratanya. Varians adalah rata-rata hitung deviasi kuadrat setiap data terhadap rata-rata hitungnya. Standar Deviasi adalah akar kuadrat dari varians dan menunjukkan standar penyimpangan data terhadap nilai rataratanya. (Octaviani, 2012). . Dalam pengerjannya peneliti menggunakan bantuan SPSS. Adapun konteks pengerjaan manualnya yaitu :

Rumus varians :

$\mathrm{S}^{2}=\frac{\sum f(x-\bar{x})^{2}}{n-1}$

Rumus standar deviasi :

$\mathrm{S}=\sqrt{\frac{\sum f(x-\bar{x})^{2}}{n-1}}$

d. Display Data (Tabel / Histogram)

Pada penelitian ini, sebagai display data penulis menggunakan table dan histogram.

\subsubsection{Uji Prasyarat Analisis tiap Variabel}

a. Uji Normalitas

Yaitu sebuah uji untuk menilai sebaran data pada variabel atau kelompok data, apakah berdistribusi normal ataukah tidak. Jika data berdistribusi normal dapat diasumsikan bahwa data diambil secara acak dari populasi normal. Uji Normalitas berguna untuk menentukan data yang telah dikumpulkan berdistribusi normal atau diambil dari populasi normal. Metode klasik dalam pengujian normalitas suatu data tidak begitu rumit. Berdasarkan pengalaman empiris beberapa pakar statistik, data yang banyaknya lebih dari 30 angka $(\mathrm{n}>30)$, maka sudah dapat diasumsikan berdistribusi normal. Biasa dikatakan sebagai sampel besar. Dalam pengerjannya peneliti menggunakan bantuan SPSS. Adapun konteks pengerjaan manualnya yaitu :

$x^{2}=\sum \frac{\left(O_{1}-E_{1}\right)}{E_{1}}$

\section{b. Uji Lineritas}

Uji linearitas dimaksudkan untuk mengetahui ada tidaknya hubungan secara linear antara variabel dependen terhadap setiap variabel independen yang hendak diuji. Jika suatu model tidak memenuhi syarat linearitas maka model regresi linear tidak bisa digunakan. (Rahmawati, 2013). Dalam pengerjannya peneliti menggunakan bantuan SPSS. Adapun konteks pengerjaan manualnya yaitu :

\subsubsection{Uji Hipotesis}

$$
\mathrm{b}=\frac{n \sum x y-\left(\sum x\right)\left(\sum y\right)}{n \sum x^{2}-\left(\sum x\right)^{2}}
$$

a. Uji Hipotesis tiap Variabel

Hipotesis yang akan diuji dalam penelitian ini berkaitan dengan ada tidaknya pengaruh antara variabel X (variabel bebas) dan variabel Y (variabel terikat). Di mana hipotesis nol (H0) yaitu hipotesis tentang tidak adanya pengaruh.Sedangkan hipotesis alternatif (H1) merupakan hipotesis yang diajukan peneliti dalam penelitian ini. Masing-masing hipotesis tersebut dijabarkan sebagai berikut:

a. $\mathrm{H} 0: \beta 1=0$, Terdapat pengaruh yang signifikan antara efektifitas Pembelajaran Jarak Jauh (PJJ) mata pelajaran PAI terhadap motivasi siswa di Cluster Koba Village Kelurahan Ciseureuh Purwakarta

b. H1 : $\beta 1 \neq 0$, Tidak terdapat pengaruh yang signifikan antara efektifitas Pembelajaran Jarak Jauh (PJJ) mata pelajaran PAI terhadap motivasi siswa di Cluster Koba Village Kelurahan Ciseureuh Purwakarta.

b. Korelasi

Teknik analisis data secara statistik inferensial lebih ditekankan pada proses generalisasi yang lebih luas dalam wilayah populasi. Nantinya, peneliti akan menarik kesimpulan berdasarkan hasil penelitian, pada sejumlah sampel terhadap populasi yang lebih besar. Metode dalam penelitian ini menggunakan analisis korelasional, dimana analisis korelasional lebih menekankan pada adanya pengaruh atau hubungan antara 2 variabel atau lebih. . Dalam pengerjannya peneliti menggunakan bantuan SPSS. Adapun konteks pengerjaan manualnya yaitu : 
$\mathrm{t}=\frac{r \sqrt{n-2}}{\sqrt{1-r^{2}}}$

keterangan :

t $\quad$ : Nilai t hitung

$\mathrm{r} \quad$ : Nilai koefisien korelasi

$\mathrm{n} \quad$ : Jumlah data pengamatan

Tabel 3. Pedoman untuk memberikan Interpretasi Koefisien Korelasi

\begin{tabular}{|c|c|}
\hline Interval Koefisien & Tingkat Hubungan \\
\hline $0.00-0.199$ & Sangat Rendah \\
\hline $0.20-0.399$ & Rendah \\
\hline $0.40-0.599$ & Sedang \\
\hline $0.60-0.799$ & Kuat \\
\hline $0.80-1.000$ & Sangat Kuat \\
\hline
\end{tabular}

c. Regresi

Uji regresi bertujuan untuk menguji hubungan yang searah atau hubungan yang berbentuk pengaruh pada suatu variable bebas dengan variable terikat. (Susetyo, 2012). Dalam penelitian ini peneliti memakai aplikasi SPSS sebagai bahan pengerjaannya. Adapun rumus dari korelasi sederhana adalah sebagai berikut :

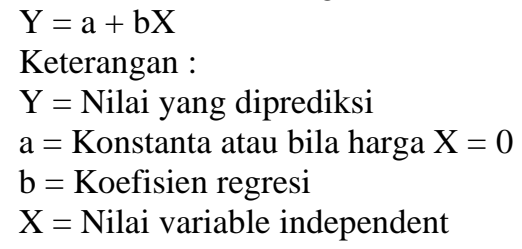

\section{HASIL DAN PEMBAHASAN}

\subsection{Deskripsi Data Tiap Variabel}

Diperoleh data dari variable $\mathrm{X}$ yaitu Efektifitas pembelajaran jarak jauh dengan nilai rata rata 87.6\% dari seluruh pernyataan. Mengacu pada presentase dan kriteria penilaian, angka tersebut ada pada interval 84 100 dengan katergori sangat baik. Dengan demikian, hal tersebut menunjukan rata rata responden efektifitas pembelajaran jarak jauh adalah sangat baik. Nilai presentase tertinggi yang diberikan responden ada pada item "Anda menyukai pembelajaran daring karena anda bisa sambil bersantai saat belajar" pada item 25, pada item tersebut presentase jawaban adalah sebesar $100 \%$ dengan kategori sangat baik. Nilai Presentase terendah yang berikan responden ada pada item "Apakah dengan cara pembelajaran daring membuat anda semakin memahami pembelajaran tersebut ?" pada item 12. Pada item tersebut presentase jawaban adalah $80.1 \%$ dengan kategori baik.

Diperoleh data dari variable Y yaitu Motivasi Belajar Siswa dengan nilai rata rata $85.7 \%$ dari seluruh pernyataan. Mengacu pada presentase dan kriteria penilaian, angka tersebut ada pada interval 84 - 100 dengan katergori sangat baik. Dengan demikian, hal tersebut menunjukan rata rata responden motivasi belajar siswa adalah sangat baik. Nilai presentase tertinggi yang diberikan responden ada pada item "Saya telah membuat jadwal pelajaran dirumah, sehingga saya mengetahui kapan saya harus belajar" dan "Saya menghabiskan sebagian besar waktu belajar untuk bergosip dengan teman" pada item 13 dan 18 , pada item tersebut presentase jawaban adalah sebesar $100 \%$ dengan kategori sangat baik. Nilai Presentase terendah yang berikan responden ada pada item "Saya suka mengunjungi perpustakaan sekolah untuk membaca buku pelajaran" pada item 05. Pada item tersebut presentase jawaban adalah $65.2 \%$ dengan kategori baik.

\subsection{Uji Prasyarat Analisis}

Berdasarkan hasil perhitungan uji normalitas variable $\mathrm{x}$ (efektifitas pembelajaran jarak jauh) dan variable y (motivasi belajar siswa) adalah sebagai berikut :

Tabel 4. Uji Normalitas Variabel X dan Y

Tests of Normality

\begin{tabular}{|c|c|c|c|c|c|c|}
\hline & \multicolumn{3}{|c|}{ Kolmogorov-Smirnov $^{\mathrm{a}}$} & \multicolumn{3}{|c|}{ Shapiro-Wilk } \\
\hline & Statistic & Df & Sig. & Statistic & $\mathrm{df}$ & Sig. \\
\hline $\mathrm{X}$ & .068 & 78 & $.200^{*}$ & .991 & 78 & .867 \\
\hline
\end{tabular}




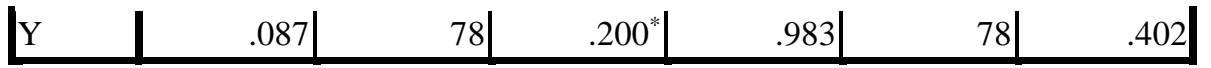

a. Lilliefors Significance Correction

*. This is a lower bound of the true significance.

Berdasarkan output diatas, diketahui bahwa nilai signifikan variable $\mathrm{X}$ sebesar 0.200 lebih besar dari 0.05 sehingga dapat disimpulkan bahwa data yang peneliti uji bersifat normal . Berdasarkan output diatas diketahui bahwa nilai signifikansi variable Y sebesar 0.200 sehingga dapat disimpulkan bahwa data berdistribusi normal.

Berdasarkan dari pengolahan data yang telah dilakukan diperoleh hasil uji linearitas sebagaimana disajikan dalam table berikut :

Tabel 5. Uji Linieritas Variabel X dan Y

$U$

i

ANOVA Table

\begin{tabular}{|c|c|c|c|c|c|c|c|}
\hline & & & $\begin{array}{l}\text { Sum of } \\
\text { Squares }\end{array}$ & Df & $\begin{array}{c}\text { Mean } \\
\text { Square }\end{array}$ & $\mathrm{F}$ & Sig. \\
\hline \multirow[t]{5}{*}{$\mathrm{x} *$} & \multirow{3}{*}{$\begin{array}{l}\text { Between } \\
\text { Groups }\end{array}$} & (Combined) & 742.258 & 22 & 33.739 & \multirow{5}{*}{$\begin{array}{r}1.419 \\
.627 \\
1.456\end{array}$} & \multirow{5}{*}{$\begin{array}{l}.147 \\
.432 \\
.133\end{array}$} \\
\hline & & Linearity & 14.918 & 1 & 14.918 & & \\
\hline & & $\begin{array}{l}\text { Deviation from } \\
\text { Linearity }\end{array}$ & 727.339 & 21 & 34.635 & & \\
\hline & \multirow{2}{*}{\multicolumn{2}{|c|}{$\begin{array}{l}\text { Within Groups } \\
\text { Total }\end{array}$}} & 1307.960 & 55 & \multirow[t]{2}{*}{23.781} & & \\
\hline & & & 2050.218 & 77 & & & \\
\hline
\end{tabular}

berdasarkan uji linearitas pada table diatas, diperoleh nilai signifikan 0.133. nilai tersebut lebih besar dari taraf kesalahan signifikan yaitu 0.05 artinya terdapat hubungan yang linear secara signifikan antara variable $\mathrm{x}$ (efektifitas pembelajaran jarak jauh) dan variebel y (motivasi belajar siswa)

\subsection{Uji Hipotesis}

Untuk hipotesis asosiatif diberikan juga hipotesis terkonfirmasi dan tidak terkonfirmasi, sebagaimana dibawah ini :

a. Ha : Terdapat pengaruh yang signifikan antara efektifitas Pembelajaran Jarak Jauh (PJJ) mata pelajaran PAI terhadap motivasi siswa di Cluster Koba Village Kelurahan Ciseureuh Purwakarta

b. Ho : Tidak terdapat pengaruh yang signifikan antara efektifitas Pembelajaran Jarak Jauh (PJJ) mata pelajaran PAI terhadap motivasi siswa di Cluster Koba Village Kelurahan Ciseureuh Purwakarta.

Untuk menjawab hipotesis tersebut dilakukan pengujian ststistik koefisien korelasi. Koefisien korelasi menunjukan kekuatan hubungan linear dan arah hubungan dua variable. Jika koefisien korelasi positif maka kedua variable mempunyai hubungan yang searah. Artinya, Jika nilai variable x (Efektivitas pembelajaran jarak jauh) tinggi maka nilai variable y (motivasi belajar siswa) rendah dan begitupun sebaliknya. Adapun uji koefisien korelasi dengan bantuan SPSS adalah sebagai berikut :

Tabel 6.Output Perhitungan Korelasi

Correlations

\begin{tabular}{|l|r|r|}
\hline & $\mathrm{X}$ & \multicolumn{1}{|c|}{$\mathrm{Y}$} \\
\hline $\mathrm{X} \quad$ Pearson Correlation & & -.085 \\
& & \\
Sig. (2-tailed) & & .458 \\
$\mathrm{~N}$ & & 78 \\
\hline
\end{tabular}




\begin{tabular}{|l|r|r|}
\hline Y Pearson Correlation & -.085 & 1 \\
& & \\
Sig. (2-tailed) & .458 & \\
$\mathrm{~N}$ & 78 & 78 \\
\hline
\end{tabular}

Dari output diatas berdasarkan nilai signifikansi variable $\mathrm{x}$ terhadap variable y sebesar $0.458<0.05$ maka dapat disimpulkan bahwa kedua variable itu memiliki hubungan atau berkorelasi. Sedangkan nilai koefisien korelasi adalah -0.85 mengacu pada table persamaan regresi maka angka tersebut berada pada interval $0.00-0.199$ dengan interprestasi bahwa antara variable $\mathrm{x}$ (efektifitas pembelajaran jarak jauh) dengan variable y (motivasi belajar siswa) memiliki hubungan sangat rendah.

Berdasarkan table diatas nilai koefisien korelasi menujukan nilai negatif yang mana variable $\mathrm{x}$ dan y mempunyai hubungan berlawanan dengan kesimpulan jika nilai variable $\mathrm{x}$ (Efektifitas pembelajaran jarak jauh) tinggi maka nilai variable y (Motivasi belajar siswa) akan rendah.

2) Uji Signifikansi

Untuk mengetahui jumlah persen variable X (Efektivitas pembelajaran jarak jauh) terlebih dahulu harus dilakukan uji signifikansi. Hal tersebut dilakukan dengan cara menghitung nilai $t$ untuk mengetahui signifikansi atau tidaknya korelasi antara variable $\mathrm{x}$ dan $\mathrm{y}$. Adapun hasil output perhitungan uji t dengan menggunakan bantuan SPSS adalah sebagai berikut :

Tabel 7. Uji Signifikansi

Coefficients $^{\mathrm{a}}$

\begin{tabular}{|c|c|c|c|c|c|}
\hline \multirow[b]{2}{*}{ Model } & \multicolumn{2}{|c|}{ Unstandardized Coefficients } & $\begin{array}{c}\text { Standardized } \\
\text { Coefficients }\end{array}$ & \multirow[b]{2}{*}{1} & \multirow[b]{2}{*}{ Sig. } \\
\hline & B & Std. Error & Beta & & \\
\hline $\begin{array}{ll}1 & \text { (Constant) } \\
\mathrm{X}\end{array}$ & $\begin{array}{r}106.444 \\
-.082\end{array}$ & $\begin{array}{r}10.489 \\
.110\end{array}$ & -.085 & $\begin{array}{r}10.148 \\
-.746\end{array}$ & $\begin{array}{l}.000 \\
.458\end{array}$ \\
\hline
\end{tabular}

a. Dependent Variable: y

Berdasarkan table diatas nilai thitung adalah -0.746 sedangkan ttabel dengan $\mathrm{df}=\mathrm{n}$ $-2=78-2=76$, dengan taraf kesalahan sebanyak $5 \%$ adalah 1.925 . dengan demikian, nilai thitung lebih kecil dari ttabel, sehingga thitung terletak didaerah penolakan Ha. Kesimpulannya berdasarkan hasil penelitian terhadap 78 responden, diperoleh keterangan bahwa tidak terdapat korelasi yang signifikansi antara variable $\mathrm{x}$ (efektifitas pembelajaran jarak jauh) terhadap variable y (motivasi belajar siswa).

3) Koefisien Determinasi

Berdasarkan hasil pengolahan data yang telah dilakukan diperoleh hasil koefisien determinasi sebagaimana disajikan dalam table berikut

Tabel 8. Koefisien Determinasi

Model Summary ${ }^{\mathrm{b}}$

\begin{tabular}{|l|r|r|r|r|}
\hline Model & \multicolumn{1}{|c|}{$\mathrm{R}$} & R Square & \multicolumn{1}{c|}{$\begin{array}{c}\text { Adjusted R } \\
\text { Square }\end{array}$} & $\begin{array}{c}\text { Std. Error of the } \\
\text { Estimate }\end{array}$ \\
\hline 1 & $.085^{\mathrm{a}}$ & .007 & -.006 & 5.175 \\
\hline
\end{tabular}

a. Predictors: (Constant), $\mathrm{x}$

b. Dependent Variable: y

Berdasarkan nilai korelasi/hubungan (R) variable $\mathrm{x}$ terhadap variable y diperoleh melalui penghitungan adalah 0.085 , sedangkan koefisien determinasi (R Square) sebesar 0.007. Dengan demikian, nilai koefisien determinasi yaitu $0.085^{2} \times 100=$ $0.7225 \times 100=72.25$ atau dapat dikatakan bahwa variable $\mathrm{x}$ (efektifitas pembelajaran jarak jauh) terdapat variable y (motivasi belajar siswa) dipengaruhi oleh variable $\mathrm{x}$ sebesar $72.25 \%$ dan sisanya $27.75 \%$ dipengaruhi factor lain diluar variable x (efektivitas pembelajaran jarak jauh).

4) Regresi

Berdasarkan hasil pengolahan data yang telah dilakukan dengan program SPSS diperoleh perhitungan regresi sebagaimana disajikan dalam table berikut : 
Tabel 9. Perhitungan Persamaan Regresi

\begin{tabular}{|l|r|r|r|r|r|}
\hline Model & Sum of Squares & Df & Mean Square & F & \multicolumn{1}{c|}{ Sig. } \\
\hline 1 Regression & 14.918 & 1 & 14.918 & .557 & $.458^{\mathrm{a}}$ \\
Residual & 2035.300 & 76 & 26.780 & & \\
Total & 2050.218 & 77 & & & \\
\hline
\end{tabular}

a. Predictors: (Constant), $\mathrm{x}$

b. Dependent Variable: y

Tabel diatas menunjukan Fhitung sebesar $=0.557$ sedangkan Ftabel dengan df1 $=\mathrm{k}-1(2-1=1)$ dan df $2=\mathrm{n}-2=78-2=76$ dengan taraf kesalahan $5 \%$ maka nilai Ftabel adalah 3.978 apabila fhitung > ftabel maka Ha diterima dan Ho ditolak. Sedangkan apabila Fhitung < Ftabel maka Ha ditolak dan Ho diterima.

Berdasarkan perbandingan nilai diatas, Fhitung > Ftabel. Sehingga dapat disimpulkan bahwa variable $\mathrm{x}$ (efektifitas pembelajaran jarak jauh) tidak terdapat pengaruh yang signifikan terhadap variable y (motivasi belajar siswa). Adapun hasil hitung korelasi dengan menggunakan SPSS adalah sebagai berikut :

Tabel 10. Output Perhitungan Koefisien Korelasi

\section{Coefficients $^{\mathrm{a}}$}

\begin{tabular}{|c|c|c|c|c|c|}
\hline \multirow[b]{2}{*}{ Model } & \multicolumn{2}{|c|}{ Unstandardized Coefficients } & \multirow{2}{*}{$\begin{array}{c}\begin{array}{c}\text { Standardized } \\
\text { Coefficients }\end{array} \\
\text { Beta }\end{array}$} & \multirow[b]{2}{*}{$\mathrm{T}$} & \multirow[b]{2}{*}{ Sig. } \\
\hline & B & Std. Error & & & \\
\hline $1 \quad$ (Constant) & 106.444 & 10.489 & & 10.148 & .000 \\
\hline $\mathrm{X}$ & -.082 & .110 & -.085 & -.746 & .458 \\
\hline
\end{tabular}

a. Dependent Variable: y

Berdasarkan table diatas, pada kolom B constant (a) adalah 106.444 sedangkan nilai trust (b) 0.550 . Sehingga persamaan regresi dapat dihitung sebagai berikut :

$\mathrm{Y}=\mathrm{a}+\mathrm{b} \mathrm{X}$

$\mathrm{Y}=106.444+(-0.082) \mathrm{X}$

Persamaan tersebut dapat diterjemahkan :

1. Konstant a sebesar 106.444 mengandung arti bahwa nilai constant a variable motivasi belajar siswa adalah 106.444

2. Koefisien regresi $X$ sebesar -0.082 menyatakan bahwa setiap penambahan $1 \%$ nilai efektivitas pembelajaran jarak jauh, maka nilai motivasi belajar siswa berkurang sebesar -0.082. Koefisien regresi tersebut bernilai negative. Sehingga dapat dikatakan bahwa arah pengaruh variable $\mathrm{X}$ terhadap $\mathrm{Y}$ adalah negative atau berlawanan.

\section{KESIMPULAN}

Dari hasil hitung uji hipotesis, didapat tes value untuk uji hipotesis variable $\mathrm{x}$ (efektifitas pembelajaran jarak jauh) adalah 36.0 dengan hipotesis yang diharapkan $60 \%$ dan nilai rata rata variable $\mathrm{x}$ sebesar $59.0 \%$. Adapun hasil uji hipotesis menggunakan aplikasi SPSS yaitu dngan derajat kealahan 5\% didapat thitung = 58.206 dan ttabel 1.925 jika thitung $>$ ttabel maka Ha diterima dan Ho ditolak, Sedangkan jika thitung < ttabel maka Ho diterima dan Ha ditolak. Apabila melihat table Uji Hipotesis pada penelitian ini thitung sebesar 58.206 lebih besar dari ttabel 1.925 maka dapat disimpulkan bahwa Ha diterima dan Ho ditolak atau "Terdapat pengaruh yang signifikan antara efektifitas Pembelajaran Jarak Jauh (PJJ) 
mata pelajaran PAI terhadap motivasi siswa di Cluster Koba Village" dengan nilai Efektifitas Pembelajaran Jarak Jauh lebih dari 60\%.

Berdasarkan hasil dan pembahasan yang peneliti paparkan pada bab sebelumnya bahwa efektifitas pembelajaran jarak jauh pada mata pelajaran PAI di Cluster Koba Village memiliki nilai 59.0\% dengan demikian variable ini memiliki kriteria peniaian cukup baik. Maka dapat disimpulkan bahwa Efektifitas Pembelajaran Jarak Jauh siswa yang bertempat tinggal di Cluster Koba Vilage tidak lebih baik dari hipotesis yang diharapkan.

Dari hasil hitung uji hipotesis, didapat tes value untuk uji hipotesis variable y (motivasi belajar siswa) adalah 43.2 dengan hipotesis yang diharapkan $60 \%$ dan nilai rata rata variable y sebesar $32.5 \%$. Adapun hasil uji hipotesis menggunakan aplikasi SPSS yaitu dengan derajat kealahan 5\% didapat thitung = 66.115 dan ttabel 1.925 jika thitung > ttabel maka Ha diterima dan Ho ditolak, Sedangkan jika thitung $<$ ttabel maka Ho diterima dan Ha ditolak. Apabila melihat table Uji Hipotesis pada penelitian ini thitung sebesar 66. 115 lebih besar dari ttabel yaitu 1.925 maka dapat disimpulkan bahwa Ha diterima dan Ho ditolak atau "Terdapat pengaruh yang signifikan antara efektifitas Pembelajaran Jarak Jauh (PJJ) mata pelajaran PAI terhadap motivasi siswa di Cluster Koba Village" dengan nilai Motivasi Belajar Siswa lebih dari $60 \%$.

Sedangkan untuk variable Y (Motivasi belajar siswa) dicluster koba Village memiliki nilai 32.5\% dengan demikian variable ini memiliki kriteria penilaian tidak baik. Maka dapat disimpulkan bahwa Motivasi Belajar Siswa yang bertempat tinggal di Cluster Koba Village tidak baik. Untuk menjawab hipotesis diatas dilakukan pengujian ststistik koefisien korelasi dengan nilai signifikansi variable $\mathrm{x}$ terhadap variable y sebesar $0.458<0.05$ maka dapat disimpulkan bahwa "kedua variable itu memiliki hubungan atau berkorelasi". Sedangkan nilai koefisien korelasi adalah -0.85 mengacu pada table persamaan regresi maka angka tersebut berada pada interval $0.00-0.199$ dengan interprestasi bahwa korelasi antara variable $\mathrm{x}$ (efektifitas pembelajaran jarak jauh) dengan variable y (motivasi belajar siswa) memiliki hubungan tetapi sangat rendah. Berdasarkan uji koefisien korelasi diatas didapat nilai negative. yang mana variable $\mathrm{x}$ dan y mempunyai hubungan berlawanan dengan kesimpulan "Jika nilai variable $\mathbf{x}$ (Efektifitas pembelajaran jarak jauh) tinggi maka nilai variable y (Motivasi belajar siswa) akan rendah".

\section{REFERENCES}

[1] Munir, Pembelajaran Jarak Jauh Berbasis Teknologi Informasi dan Komunikasi. Bandung: Alfabeta, 2012.

[2] C. Komariah, S. Uwes, M. Drajat, and I. Tabroni, "Peran Orang Tua Dalam Pembinaan Akhlak Anak Melalui Media Internet," J. Ilm. Edukatif, vol. 7, no. 1, pp. 25-36, 2021.

[3] Oemar Hamalik, Proses Belajar Mengajar. Jakarta: Bumi Aksara, 2001.

[4] Winfred F.Hill, Theories of Learning. Bandung: Nusa Media, 2012.

[5] Hamzah B Uno, Teori Motivasi dan Pengukuran. Gorontalo: Bumi Aksara, 2006.

[6] Daryanto and S. Karim, Pembelajaran Abad 21. Yogyakarta: Gava Media, 2016.

[7] Isbandi Rukimto Adi, Psikologi,Pekerjaan Sosial dan Ilmu Kesejahteraan Sosial: Dasar Dasar Pendidikan. Jakarta: Grafindo Persada, 1994.

[8] Nini Subini, Mengatasi Kesulitan Belajar Pada Anak. Madiun: Javalitera, 2012.

[9] I. Tabroni, MODEL PENDIDIKAN ISLAM: Teknik Mendidik Anak dengan Treatment di Era 4.0. Bandung: CV Cendekia Press, 2019.

[10] Sugiyono, Metode Penelitian Pendidikan. Bandung: Alfabeta, 2010.

[11] Supardi, Aplikasi Statistika dalam Penelitian Konsep Statistika yang Lebih Komprehensif. Jakarta: Change Publication, 2013. 